\title{
Tenascin-R Is an Intrinsic Autocrine Factor for Oligodendrocyte Differentiation and Promotes Cell Adhesion by a Sulfatide- Mediated Mechanism
}

\author{
Penka Pesheva, ${ }^{1}$ Sergio Gloor, ${ }^{3}$ Melitta Schachner, ${ }^{4}$ and Rainer Probstmeier ${ }^{2}$ \\ ${ }^{1}$ Department of Physiology, Neurophysiology and ${ }^{2}$ Department of Biochemistry, Institute of Animal Anatomy and \\ Physiology, University of Bonn, Bonn, Germany, and ${ }^{3}$ Laboratory of Biochemistry and ${ }^{4}$ Chair of Neurobiology, Swiss \\ Federal Institute of Technology, 8092 Zürich, Switzerland
}

\begin{abstract}
$\mathrm{O}^{+}$oligodendrocyte (OL) progenitors in the mammalian CNS are committed fully to terminal differentiation into myelinforming cells. In the absence of other cell types in vitro, OL differentiation reproduces the in vivo development with a correct timing, suggesting the existence of an intrinsic regulatory mechanism that presently is unknown. We have examined the effect of two isoforms of the extracellular matrix (ECM) molecule tenascin-R (TN-R), which is expressed by OLs during the process of myelination, on the adhesion and maturation of OLs in vitro. Here we show that the substrate-bound molecules supported the adhesion of $\mathrm{O}^{+}$OLs independently of the CNS region or age from which they were derived. At the molecular level this process was mediated by protein binding to membrane surface sulfatides (Sulf), as indicated by the interference
\end{abstract}

of O4 antibody and Sulf with the attachment of OLs or other Sulf $^{+}$cells, erythrocytes, to TN-R substrates and by direct protein-glycolipid binding studies. In the absence of plateletderived growth factor (PDGF), exogenous TN-R induced myelin gene expression and the upregulation of its own synthesis by cultured cells, resulting in a rapid terminal differentiation of $\mathrm{O}_{4}^{+}$ progenitors. Our findings strongly suggest that TN-R represents an intrinsic regulatory molecule that controls the timed OL differentiation by an autocrine mechanism and imply the relevance of $\mathrm{TN}-\mathrm{R}$ for $\mathrm{CNS}$ myelination and remyelination.

Key words: cell adhesion; extracellular matrix; glycosphingolipid; myelination; oligodendrocyte differentiation; sulfatide; tenascin- $R$
In the mammalian CNS the differentiation of oligodendrocytes (OLs) is characterized by the sequential expression of myelinspecific molecules, which finally leads to the formation of the myelin sheath. The earliest stages of macroglial development take place in the ventral regions of the neural tube (for spinal cord) and the ventricular zones of the neonatal mammalian forebrain, where the first OL progenitors characterized by simple morphology and the expression of the disialoganglioside GD3 and/or the $\mathrm{O} 4$ antigen(s) proliferate and migrate into the presumptive white matter (Goldman and Vaysse, 1991; Noble, 1991; Skoff and Knapp, 1991; Miller, 1996). There, cells become postmitotic and differentiate into mature OLs of complex morphology, a process that correlates with the expression of myelin-specific lipids (membrane surface sulfatides, Sulf, and galactocerebrosides, GalC) and proteins (myelin basic protein, MBP; myelin-associated glycoprotein, MAG; and proteolipid protein, PLP). In the absence of other cell types in vitro, $\mathrm{O}^{+}{ }^{+} \mathrm{GalC}^{-}$progenitor cells are committed fully to terminal differentiation, in contrast to myelinating Schwann cells in the PNS, which need axonal contact for the expression of myelin proteins and glycolipids (GLs; Gard and Pfeiffer, 1989; Jessen and Mirsky, 1991). These observations strongly suggest

\footnotetext{
Received Jan. 21, 1997; revised March 25, 1997; accepted April 7, 1997.

Parts of this study were supported by the BONFOR Research Program (P.P.), the Swiss National Science Foundation (S.G.), and the Deutsche Forschungsgemeinschaft (R.P.). We thank I. Bahnmüller for expert technical help and K. Winterhalter (Swiss Federal Institute of Technology, Zürich) for support during a critical stage of this work (P.P.).

Correspondence should be addressed to Dr. Penka Pesheva, Department of Physiology, Neurophysiology, University of Bonn, Wilhelmstrasse 31, 53111 Bonn, Germany.

Copyright (C) 1997 Society for Neuroscience 0270-6474/97/174642-10\$05.00/0
}

that the mechanism promoting the timed differentiation of OL progenitors is intrinsic for these cells. In different regions and tracts of the brain and the spinal cord, OL differentiation and myelin formation occur, however, asynchronously, suggesting that the regulation of myelination can be dominated by local environmental signals (Rozeik and Von Keyserlingk, 1987; Schwab and Schnell, 1989).

As previously shown, the extracellular matrix (ECM) glycoprotein tenascin-R (TN-R)/janusin, a member of the TN multigene family that exists in two major molecular isoforms of 160 (TN-R $160)$ and $180 \mathrm{kDa}$ (TN-R 180), is expressed in the CNS by cells of the O-2A cell lineage, OLs and type-2 astrocytes (Pesheva et al., 1989; Bartsch et al., 1993; Erickson, 1993). The protein is expressed additionally by small subsets of CNS neurons (mainly interneurons and motoneurons) during postnatal development and in adulthood (Fuss et al., 1993; Wintergerst et al., 1993). The primary structure of human TN-R shows very high homology (93\%) to rat TN-R, and, similar to rodents, TN-R mRNA was found expressed exclusively in the human CNS (Carnemolla et al., 1996). So far two isoforms generated by alternative splicing of the sixth FN III homologous repeat have been identified, although the actual difference between TN-R 160 and TN-R 180 at a protein level is yet a matter of consideration (Pesheva et al., 1989; Fuss et al., 1993; Carnemolla et al., 1996). The expression of TN-R by OLs and in myelin coincides with the process of myelination, whereafter both mRNA and protein levels are downregulated to lower values in adulthood (Pesheva et al., 1989; Fuss et al., 1993). Mammalian TN-R is adhesive for astrocytes and antiadhesive for various CNS neurons, i.e., it causes the detachment of neuronal cells from and inhibits axonal outgrowth into TN-R-containing 
substrates in vitro by its interaction with the neuronal protein F3/11 (Pesheva et al., 1989, 1991, 1993; Morganti et al., 1990; Taylor et al., 1993).

The close correlation between myelinogenesis and TN-R expression in the developing rodent brain prompted us to investigate the possible role of the glycoproteins in the regulation of OL differentiation. We report that TN-R 160 and TN-R 180 promote the adhesion of $\mathrm{O}^{+}{ }^{+}$OLs by a Sulf-mediated mechanism and induce the upregulation of TN-R and myelin protein expression, suggesting an autocrine TN-R-mediated mechanism of OL differentiation.

\section{MATERIALS AND METHODS}

Materials. HBSS $\left(\mathrm{Ca}^{2+} / \mathrm{Mg}^{2+}\right.$-free), Basal Medium Eagle (BME), DMEM (for SATO medium), and horse serum (HS) were purchased from Life Technologies (Eggenstein, Germany). TN-R 160 and TN-R 180 were immunoaffinity-purified from adult mouse brain (Pesheva et al., 1989). The fraction of brain polar GLs was prepared from adult mice as described elsewhere (Hakomori and Siddiqui, 1974) and contained $\mathrm{O}^{+}$ and $\mathrm{O}^{+}$GLs (mainly Sulf and $\mathrm{GalC}$ ), as determined by solid phase ligand-binding assay and thin layer chromatography. Bovine serum albumin (BSA, fatty acid-free); laminin (LN, from EHS sarcoma); monosialoganglioside GM1, GalC, Sulf, psychosine (all from bovine brain); sphingosine (from bovine brain cerebrosides); and galactosyl diglyceride (from wheat flour) were purchased from Sigma (Deisenhofen, Germany). The GRGDS peptide was purchased from Boehringer Mannheim (Mannheim, Germany). Throughout this study the following mouse monoclonal antibodies to TN-R and OL surface molecules were used: 597, recognizing TN-R 180 in mouse brain, and 596, recognizing both TN-R 160 and TN-R 180 (Pesheva et al., 1989); A2B5, recognizing gangliosides on immature glial cells and neurons (Fredman et al., 1984); O4, recognizing Sulf/seminolipids expressed by OLs and in myelin; and O1, specific for cell surface galactolipids (mainly GalC) expressed by mature OLs (Bansal et al., 1989). Monoclonal rat antibodies to MBP (Brunner et al., 1989) and the HNK-1 carbohydrate structure (Künemund et al., 1988) and polyclonal rabbit antibodies to TN-R (Jung et al., 1993), NCAM (pNCAM) and MAG (pMAG), immunoaffinity-purified on immobilized antigens (Probstmeier et al., 1990), also were used. Fluorescein-labeled secondary antibodies were purchased from Dianova (Hamburg, Germany). Secondary antibodies coupled with horseradish peroxidase (HRP) were purchased from Dako (Hamburg, Germany).

OL cell cultures. OLs were obtained from cerebral glial cultures of neonatal ICR mice (Morganti et al., 1990). After $7 \mathrm{~d}$ of culture in BME containing $5 \% \mathrm{HS}$, OLs were shaken off the astrocytic monolayer, collected by centrifugation $\left(600 \times g\right.$ for $10 \mathrm{~min}$ at $\left.4^{\circ} \mathrm{C}\right)$, and resuspended in modified SATO medium (Trotter et al., 1989). Cells then were plated onto poly-L-lysine (PLL)-coated surfaces $(0.1 \mathrm{mg} / \mathrm{ml}$ in water), TN-R 160 , TN-R 180, or LN (all at $20 \mu \mathrm{g} / \mathrm{ml}$ in PBS, pH 7.2) at a density of $0.5 \times$ $10^{6}$ cells $/ \mathrm{ml}$; the cells were maintained for various times in culture and analyzed by indirect immunofluorescence or Western blotting (Pesheva et al., 1989). For cell adhesion assays, OLs were shaken off the astrocytic monolayer after $8 \mathrm{~d}$ of culture. This procedure yielded a cell population containing a low number of $\mathrm{GD}^{+} \mathrm{O}^{-} \mathrm{GFAP}^{-}$OL precursor cells $\left(\sim 15 \%\right.$ of the total cell number) and enriched in $\mathrm{O}^{+} \mathrm{GalC}^{-} \mathrm{O}-2 \mathrm{~A}$ progenitor cells $(\sim 35 \%)$ and $\mathrm{O}^{+} \mathrm{GalC}^{+} \mathrm{OLs}(\sim 50 \%)$. For simplicity, the latter two cell types will be referred to as $\mathrm{O}^{+}{ }^{+}$OLs throughout the study.

Erythrocyte preparation. Erythrocytes were isolated from fresh rabbit blood (Nowak et al., 1976), treated with 1\% trypsin in HBSS for $1 \mathrm{hr}$ at $37^{\circ} \mathrm{C}$, and subsequently washed in ice-cold PBS. Cells were treated further with $1 \%$ glutaraldehyde in PBS for $1 \mathrm{hr}$ at $4^{\circ} \mathrm{C}$, washed three times $(600 \times g$ for $10 \mathrm{~min})$ with $0.2 \mathrm{M}$ glycine in PBS, and washed twice with PBS. Single-cell suspensions (5\% in PBS containing $0.02 \%$ sodium azide) were stored at $4^{\circ} \mathrm{C}$.

Short-term adhesion assays. The procedure used has been described elsewhere (Pesheva et al., 1993). In antibody perturbation experiments, OLs were plated onto the substrates in the presence of monoclonal antibodies to surface membrane GLs or the HNK-1 carbohydrate (O4, O1, anti-HNK-1, $100 \mu \mathrm{g} / \mathrm{ml}$ ), polyclonal antibodies pNCAM or pMAG, or RGD-containing peptide (all at $50 \mu \mathrm{g} / \mathrm{ml}$ ). In GL perturbation experiments, substrates were preincubated with different polar GLs in PBS containing $1 \% \mathrm{BSA}$ for $1 \mathrm{hr}$ at $37^{\circ} \mathrm{C}$. Substrates subsequently were washed three times with cold PBS.

Solid phase ligand-binding assays. Different polar GLs dissolved in chloroform/methanol (2:1) were allowed to dry in glass tubes and redissolved in PBS by vigorous vortexing. Wells of microtiter plates (Falcon 3912; Becton Dickinson, Heidelberg, Germany) were coated with 100 $\mu \mathrm{l} /$ well of each GL (at a concentration of 0.5 or $1 \mu \mathrm{g} / \mathrm{ml}$ ) for $1 \mathrm{hr}$ at $37^{\circ} \mathrm{C}$. Alternatively, GLs were redissolved in absolute alcohol by vigorous vortexing, and wells were coated with $100 \mu \mathrm{l} /$ well of each GL. Ethanol was allowed to evaporate at room temperature, and plates were incubated further overnight at $4^{\circ} \mathrm{C}$. Then unsaturated binding sites on the plastic were blocked for $2 \mathrm{hr}$ at room temperature with 2\% BSA in PBS (200 $\mu \mathrm{l} /$ well). Wells subsequently were washed with cold PBS, and the binding of biotinylated (with $N$-hydroxysuccinimide biotin ester, Sigma, Deisenhofen, Germany) TN-R 160 and TN-R $180(2 \mu \mathrm{g} / \mathrm{ml}$ in PBS containing $1 \% \mathrm{BSA}, 100 \mu \mathrm{l} /$ well) was determined after $2 \mathrm{hr}$ of incubation at $37^{\circ} \mathrm{C}$ by using HRP-conjugated streptavidin (Sigma; diluted in PBS containing 1\% BSA, $100 \mu \mathrm{l} /$ well) for detection. Similar results were obtained when unlabeled TN-R detected by polyclonal antibodies to TN-R and HRPconjugated goat anti-rabbit IgG antibodies were used for binding studies.

Sandwich ELISA. For quantification of TN-R protein, OL-conditioned SATO medium was analyzed by sandwich ELISA, using monoclonal antibodies to TN-R as a linker (596 and 597, at $20 \mu \mathrm{g} / \mathrm{ml}$ ) and polyclonal antibodies to TN-R for detection. After incubation of OL-conditioned media $\left(2 \mathrm{hr}\right.$ at $37^{\circ} \mathrm{C}, 100 \mu \mathrm{l} /$ well $)$, polyclonal antibody binding $(2 \mathrm{hr}$ at $37^{\circ} \mathrm{C}$ ) was detected by anti-rabbit IgG conjugated with alkaline phosphatase (Sigma, Deisenhofen, Germany). Values for the TN-R content under different culture conditions were plotted onto a standard curve prepared in parallel from purified TN-R (in the range from $5 \mu \mathrm{g} / \mathrm{ml}$ to 3 $\mathrm{pg} / \mathrm{ml}$ ) and represented as mean $\pm \mathrm{SD}$, performed in triplicate.

Western blot analyses. Cultured OLs were detached from the substrates by pipetting and collected by centrifugation $\left(600 \times g\right.$ for $10 \mathrm{~min}$ at $\left.4^{\circ} \mathrm{C}\right)$. Cells were extracted then with $20 \mathrm{~mm}$ Tris- $\mathrm{HCl}, \mathrm{pH} 7.4,150 \mathrm{~mm} \mathrm{NaCl}, 10$ mM EDTA and $0.5 \%$ Triton $\mathrm{X}-100$ for $1 \mathrm{hr}$ at $4^{\circ} \mathrm{C}$, and insoluble material was cleared by centrifugation $\left(100000 \times g\right.$ for $20 \mathrm{~min}$ at $\left.4^{\circ} \mathrm{C}\right)$. The resulting protein extracts (from $1 \times 10^{6}$ cells/lane) were subjected to SDS-PAGE, using 6-20\% gradient polyacrylamide slab gels and analyzed further by Western blotting by using pNCAM, pMAG, or monoclonal antibody to MBP and the ECL method for detection (Amersham, Braunschweig, Germany). TN-R released into the culture medium from OLs maintained on PLL or PLL plus TN-R was immunoprecipitated by using polyclonal antibodies to TN-R and Pansorbin cells (Calbiochem, Bad Soden, Germany) as a carrier. Immunoprecipitates were subjected to SDS-PAGE and Western blot analysis with monoclonal antibody 596. For ECL detection, the Tropix Western-Light Plus kit (Tropix, Wallisellen, Switzerland) was used.

Reverse transcriptase-PCR (RT-PCR). Poly $\left(\mathrm{A}^{+}\right) \mathrm{RNA}$ was isolated from $2 \times 10^{6}$ OLs maintained on PLL or PLL plus TN-R by Oligotex purification (Qiagen, Basel, Switzerland). Poly $\left(\mathrm{A}^{+}\right)$RNA (110 ng) was used for oligo dT-primed single-strand cDNA synthesis with superscript reverse transcriptase (BRL, Basel, Switzerland) in $50 \mu \mathrm{l}$ of reaction volume. RNA was hydrolyzed with RNase H. Single-strand cDNA $(4 \mu \mathrm{l})$ was amplified in $20 \mu \mathrm{l}$ of reaction volume, using the rat TN-R-specific primers 5'-GACATACAAGTCCACCGAT-3' (upstream primer) and 5'-CTGTGAGACGATGGATGTA-3' (downstream primer) in $10 \mathrm{mM}$ Tris- $\mathrm{HCl}, \mathrm{pH} 9.0,50 \mathrm{mM} \mathrm{KCl}, 1.5 \mathrm{mM} \mathrm{MgCl}_{2}$, $0.1 \%$ Triton X-100, $0.2 \mu \mathrm{M} \mathrm{dNTP}$, and $0.25 \mu \mathrm{M}$ primer each. This amplification led to a 827 bp product. As control, GAPDH-specific primers were used with $1 \mu \mathrm{l}$ of template cDNA. Products were amplified through 35 cycles of $45 \mathrm{sec}$ at $94^{\circ} \mathrm{C}, 45 \mathrm{sec}$ at $50^{\circ} \mathrm{C}, 90 \mathrm{sec}$ at $72^{\circ} \mathrm{C}$. Eight microliters were analyzed on $1.3 \%$ agarose gels. For the GAPDH- and TN-R-specific PCR products, band intensities were analyzed by using National Institutes of Health Image software and expressed as the mean \pm SD of triplicate assays.

\section{RESULTS}

\section{Adhesion of oligodendrocytes to tenascin-R substrates}

Cultured OLs synthesize and secrete the two major TN-R isoforms also found in brain tissue (Jung et al., 1993). To examine whether the proteins can serve as substrates for cell adhesion, we plated OLs derived from cerebral glial cultures (Morganti et al., 1990) onto substrate-bound TN-R 160, TN-R 180, PLL, or LN and maintained them for $24 \mathrm{hr}$ in culture (Fig. 1). In contrast to CNS neurons, TN-R 160 and TN-R 180 supported the stable adhesion and process formation of OLs. On LN or PLL substrates, cells developed a highly branched process network, 

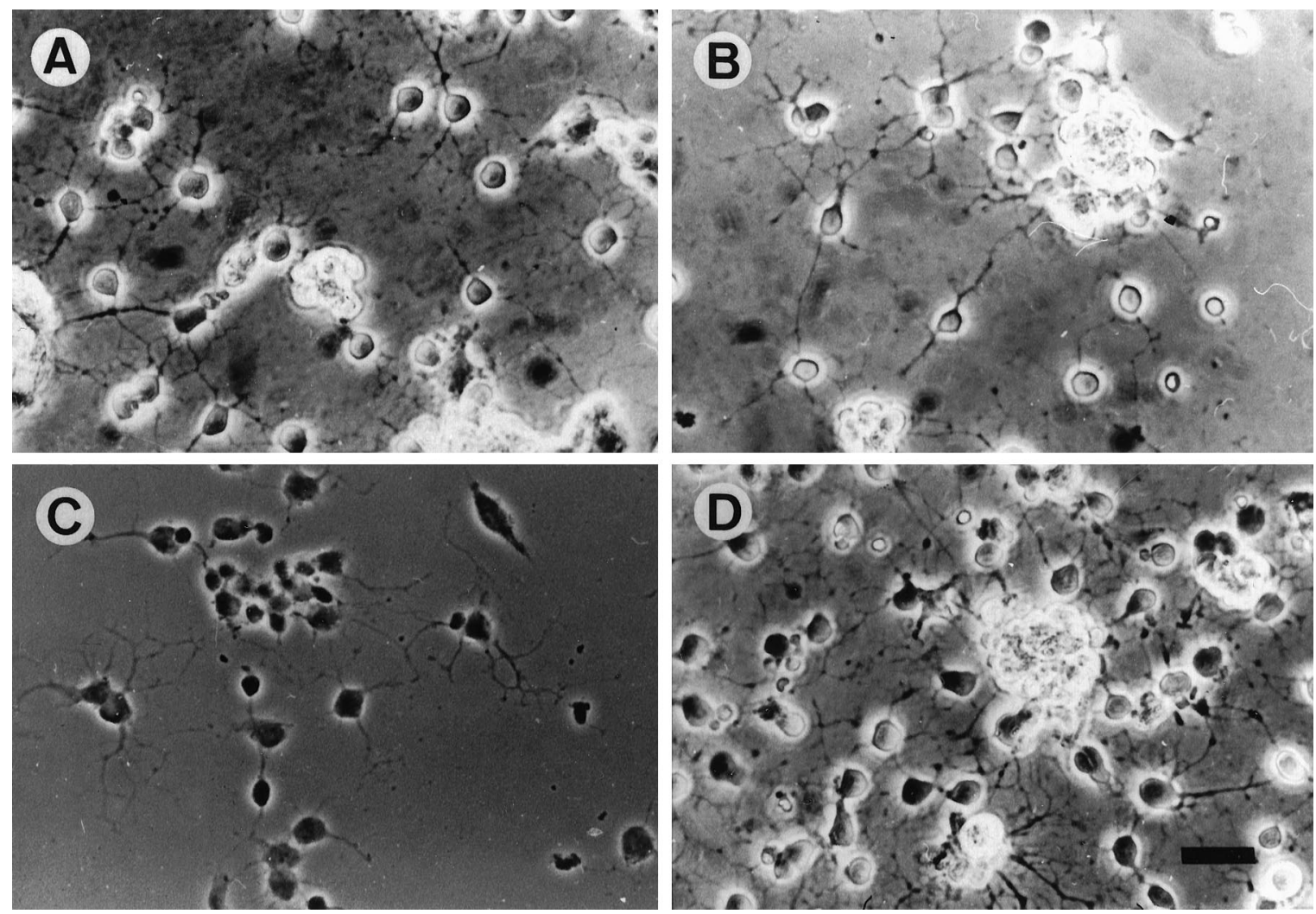

Figure 1. Adhesion pattern of OLs on TN-R, LN, and PLL substrates. OLs were plated onto TN-R $160(A)$, TN-R $180(B)$, PLL $(C)$, and LN $(D)$ substrates in modified SATO medium; cell adhesion and process formation were examined after $24 \mathrm{hr}$ of culture. Scale bar, $25 \mu \mathrm{m}$.

whereas TN-R promoted clustering of cell bodies and the projection of long and less branched processes. These cells did not proliferate, as judged by the lack of bromodeoxyuridine incorporation. Notably, OLs derived from optic nerve, telencephalon, and cerebellum of different ages (postnatal day 1-14) displayed similar adhesion patterns on TN-R substrates, suggesting that the adhesive substrate properties of the molecule toward OLs are not restricted to cells of a certain CNS region or age.

\section{Interaction of tenascin-R with oligodendrocytes is mediated by sulfatides}

In the search for the molecular mechanisms underlying the interaction of TN-R with OLs, we took into account the observation that all OLs adhering to TN-R substrates were $\mathrm{O}^{+}{ }^{+}$. Furthermore, in mixed neural cell cultures or cultures enriched in OLs, TN-R mostly seems to be associated with $\mathrm{O}^{+}$progenitor cells and OLs, an expression pattern that closely correlates with the developmental expression and localization of the molecules in vivo (Pesheva et al., 1989; Warrington and Pfeiffer, 1992; Jung et al., 1993). We next examined the interaction between TN-R and OLs by a short-term adhesion assay in the presence of antibodies to OL surface molecules or RGD-containing peptide, which has been shown to mediate the binding of OLs to glia-derived matrix and to inhibit myelinogenic expression by OLs (Cardwell and Rome, 1988a,b). Under these conditions cell adhesion to $\mathrm{LN}$ was not affected by antibodies to OL surface molecules (data not shown). After $1 \mathrm{hr}$ of incubation, $\mathrm{GD}^{+} \mathrm{O} 4^{-}$OL progenitors (a minor cell population present in the cell suspensions) did not adhere to TN-R substrates (R. Probstmeier, M. Michels, T. Franz, P. Pesheva, unpublished data). $\mathrm{O}^{+} \mathrm{OLs}\left(\mathrm{O} 4^{+} \mathrm{GalC}^{-}\right.$progenitors and $\mathrm{O} 4{ }^{+} \mathrm{GalC}^{+} \mathrm{OLs}$ ) adhered to $\mathrm{TN}-\mathrm{R}$ in a O4-dependent manner, as suggested by the selective interference of $\mathrm{O} 4$ antibodies with cell adhesion to both TN-R 160 and TN-R 180, but not to LN (Fig. 2A, for TN-R). After $1 \mathrm{hr}$ of incubation in the presence of $\mathrm{O} 1$ antibody, the adhesion of $4^{+}$OLs to TN-R 180 only was inhibited by $\sim 50 \%$. We further examined the effect of different glycosphingolipids expressed by OLs on cell attachment to TN-R substrates (Fig. 2B, left panel). The interaction of $\mathrm{O}^{+} \mathrm{OLs}$ with substrate-bound TN-R was inhibited almost completely by Sulf as well as by the fraction of brain polar GLs containing Sulf, whereas GalC, monosialoganglioside GM1, and sphingosine did not affect binding. If Sulf are cellular receptors for TN-R, then Sulf ${ }^{+}$cells other than OLs, such as erythrocytes (Hansson et al., 1978), also should adhere to TN-R substrates by a O4/Sulf-dependent mechanism. The erythrocytes used in our studies were $\mathrm{O}^{+}$(our unpublished data), and after $1 \mathrm{hr}$ of incubation these cells bound strongly to both TN-R 160 and TN-R 180 (Fig. $2 B$, right panel, for TN-R 160). Cell attachment to the substrates was abolished almost completely in the presence of the fraction of brain polar GLs and, to a similar extent, by O4 antibodies and Sulf (Fig. $2 B$, for Sulf).

Finally, we studied the interaction of the two TN-R isoforms with polar GLs by a solid phase ligand-binding assay. The fraction of brain polar GLs or individual polar GLs was immobilized in the wells of microtiter plates, and the binding of TN-R 160 and TN-R 180 was determined after 2 hr of incubation at $37^{\circ} \mathrm{C}$ by using polyclonal antibodies to TN-R or biotinylated TN-R (Fig. 3). TN-R isoforms bound most strongly to Sulf, i.e., sulfogalactose-containing glycosphingolipids, or the $\mathrm{Sulf}^{+}$fraction of brain polar GLs, and bound much weaker to galactose-containing glycosphingolipids such as GalC, galactosyl diglyceride, and psychosine (a 1- $\beta$-D-galactosylsphingosine), but not to sphingosine (Fig. 3A). Notably, TN-R 160 and 
A

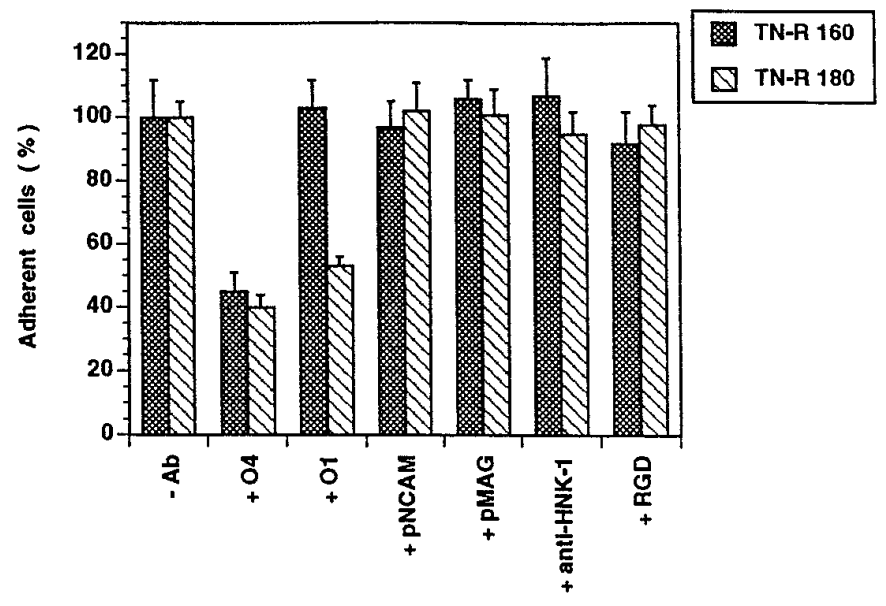

B

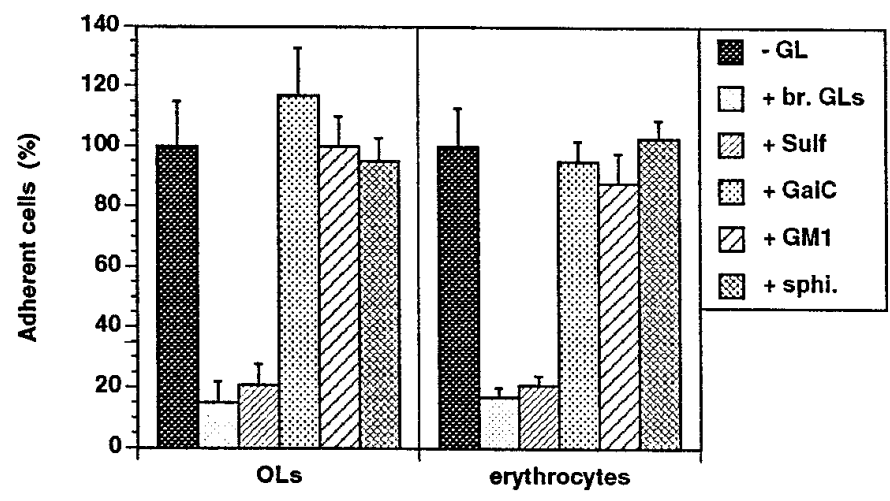

Figure 2. Effect of antibodies to OL surface molecules and RGDcontaining peptide $(A)$ and different polar GLs $(B)$ on cell attachment to TN-R substrates. $A$, OLs were plated onto TN-R 160 or TN-R 180 either in the absence $(-A b)$ or presence of monoclonal antibodies to surface membrane GLs $(+O 4,+O 1,100 \mu \mathrm{g} / \mathrm{ml})$, polyclonal antibodies to NCAM $(+p N C A M, 50 \mu \mathrm{g} / \mathrm{ml})$ and MAG $(+p M A G, 50 \mu \mathrm{g} / \mathrm{ml})$, rat monoclonal antibody to the L2/HNK-1 carbohydrate (+ anti-HNK-1, 100 $\mu \mathrm{g} / \mathrm{ml})$, or RGD-containing peptide $(+R G D, 50 \mu \mathrm{g} / \mathrm{ml}) . B$, TN-R 160 substrates were preincubated in the absence $(-G L)$ or presence of a polar GL fraction from adult mouse brain $(+b r . G L s, 20 \mu \mathrm{g} / \mathrm{ml})$, Sulf $(+$ Sulf, $5 \mu \mathrm{g} / \mathrm{ml})$, GalC (+ GalC, $10 \mu \mathrm{g} / \mathrm{ml})$, monosialoganglioside (+ GM1, 10 $\mu \mathrm{g} / \mathrm{ml}$ ) and sphingosine $(+s p h i ., 5 \mu \mathrm{g} / \mathrm{ml}$ ), and OLs (left panel), or erythrocytes (right panel) were plated onto the substrates. The number of adherent cells after $1 \mathrm{hr}$ of incubation in the absence of additives was set as $100 \%$. Values represent the mean \pm SD of four (for O4 antibody, Sulf, GalC, GM1, and sphingosine) and two (for the other antibodies, RGDcontaining peptide and $b r$. GLs) independent experiments performed in triplicate and related to the values in the absence of additives $(100 \%)$.

especially TN-R 180 bound more readily to psychosine than to the other galactosphingolipids, whereas minimal binding was detectable on the monosialoganglioside GM1. TN-R 160 and TN-R 180 bound specifically to immobilized Sulf in a dosedependent and saturable manner (Fig. 3B).

\section{Effect of tenascin-R on the differentiation of $\mathrm{O4}^{+}$ oligodendrocytes in vitro}

To study the effect of the two TN-R isoforms on the differentiation of cultured $\mathrm{O}^{+}$OLs, cells were maintained on PLL, TN-R coated on top of PLL (PLL + TN-R), or TN-R alone, and the expression of differentiation marker molecules was examined by indirect immunofluorescence (Fig. 4, Table 1). OLs maintained


Figure 3. Binding of TN-R 160 and TN-R 180 to polar GLs, as determined by solid phase ligand-binding assay. The fraction of brain polar GLs (br. GLs, $2 \mu \mathrm{g} / \mathrm{ml}$ in PBS) or Sulf, GalC, galactosyl diglyceride (GDG), psychosine ( psy.), GM1, and sphingosine (sphi., all at $1 \mu \mathrm{g} / \mathrm{ml}$ in PBS) were coated into wells of microtiter plates, and the binding of biotinylated TN-R was determined after $2 \mathrm{hr}$ of incubation at $37^{\circ} \mathrm{C}(A) . B$, Immobilized Sulf (at $0.5 \mu \mathrm{g} / \mathrm{ml}$ in $100 \%$ ethanol) was incubated with increasing amounts of $T N-R 160$ or $T N-R 180(2-50 \mu \mathrm{g} / \mathrm{ml})$. Bound protein was detected by a subsequent incubation with polyclonal antibodies to TN-R $\left(2 \mathrm{hr}\right.$ at $\left.37^{\circ} \mathrm{C}\right)$, and antibody binding was visualized by using HRP-conjugated goat anti-rabbit IgG and ABTS (2,2-azino-di-[3-ethylbenzthiazoline sulfonate(6)]; Boehringer Mannheim). Background binding to BSA was subtracted from the values obtained for the binding to different GLs. The maximal absorbance at $405 \mathrm{~nm}$ for the binding of each TN-R isoform to Sulf was set as 1.0. Values represent the mean $\pm \mathrm{SD}$ of three $(A)$ or two $(B)$ experiments performed in triplicate.

on PLL developed a highly branched process network, and the majority of them was $\mathrm{O}^{+}(\sim 80 \%)$ and $\mathrm{O}^{+}(\sim 50 \%)$. On TNR-containing substrates, OLs extended less-branched processes and were labeled by the O4 (100\%) and O1 antibodies $(96 \%)$. 


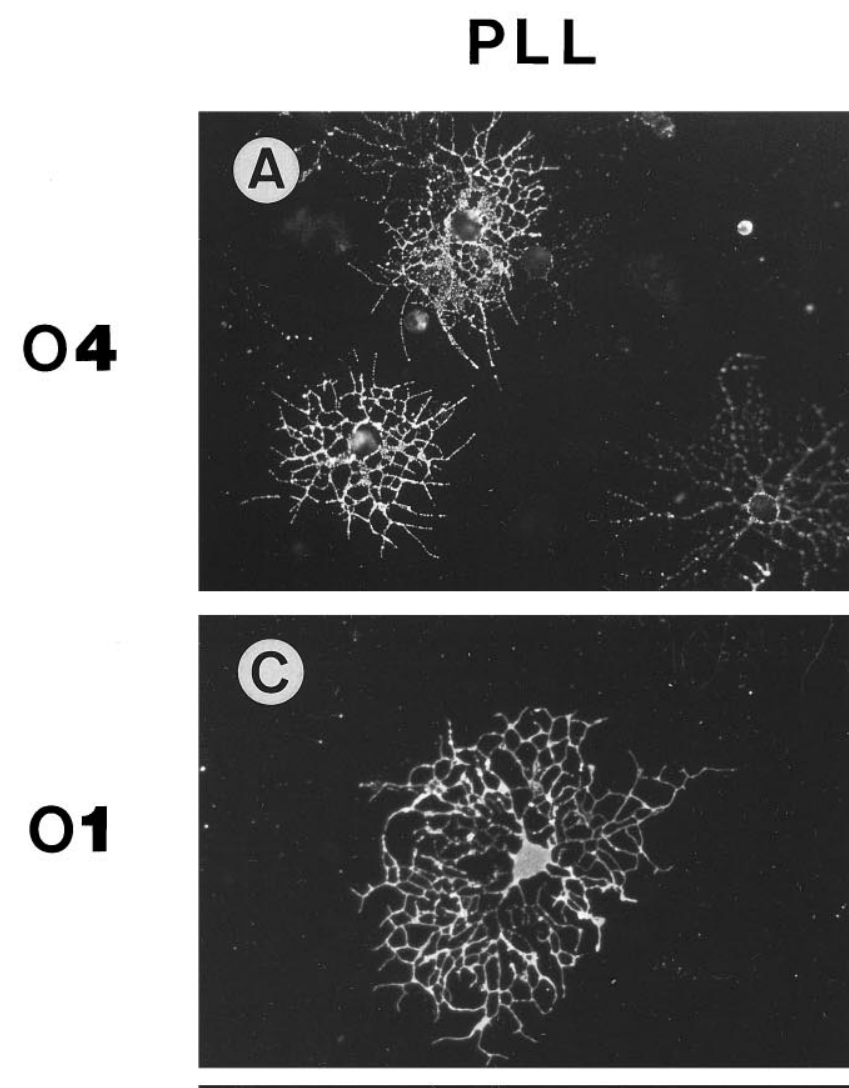

\section{PLL + TN-R}


Figure 4. Immunocytochemistry of OL marker molecules expressed by cultured OLs in the presence of exogenous TN-R. OLs were plated onto $P L L$ $(A, C, E, G)$ or $P L L+T N-R$ substrates $(B, D, F, H)$ in modified SATO medium. The expression of $O 4(A, B), O 1(C, D), M B P(E, F)$, and $P L P(G, H)$ was examined after $2 \mathrm{~d}$ of culture by indirect immunofluorescence. Scale bar, $30 \mu \mathrm{m}$. Note the increase in $M B P$ and $P L P$ expression in the cell bodies and processes of OLs cultured on PLL $+T N-R$, as compared with the low myelin protein expression by OLs on PLL defined to the cytoplasm (E, $G$, arrowheads). 
Table 1. Expression of differentiation stage-specific markers by OLs cultured on PLL and TN-R-containing substrates

\begin{tabular}{llrlll} 
Substrate & NCAM $^{+}$ & $\mathrm{A}_{2 B 5}$ & $\mathrm{O}^{+}$ & $\mathrm{O}^{+}$ & $\mathrm{MBP}^{+}$ \\
\hline PLL & 100 & $20 \pm 8$ & $84 \pm 3$ & $50 \pm 7$ & $25 \pm 3^{a}$ \\
PLL + TN-R & 100 & $10 \pm 5$ & 100 & $96 \pm 5^{b}$ & $90 \pm 4$ \\
TN-R & 100 & $8 \pm 4$ & 100 & $91 \pm 6^{b}$ & $86 \pm 8$
\end{tabular}

OLs and OL progenitors derived from cerebral glial cultures were plated onto PLL, $\mathrm{PLL}+\mathrm{TN}-\mathrm{R}$, and TN-R and maintained for $2 \mathrm{~d}$ in vitro in modified SATO medium. After this culture period cells were stained by indirect immunofluroescence with the antibodies A2B5, O4, O1 or monoclonal antibodies to NCAM and MBP. The percentages of immunoreactive cells \pm SD are shown. For each marker the number of positive cells was counted in equivalent microscopic fields of comparable cell densities and related to the total cell number of these fields ( $\sim 1500$ for each marker). ${ }^{a}$ Weak immunoreactivity defined predominantly to the cytoplasm.

${ }^{b}$ Immunoreactivities of various intensities distributed in cell bodies and processes.

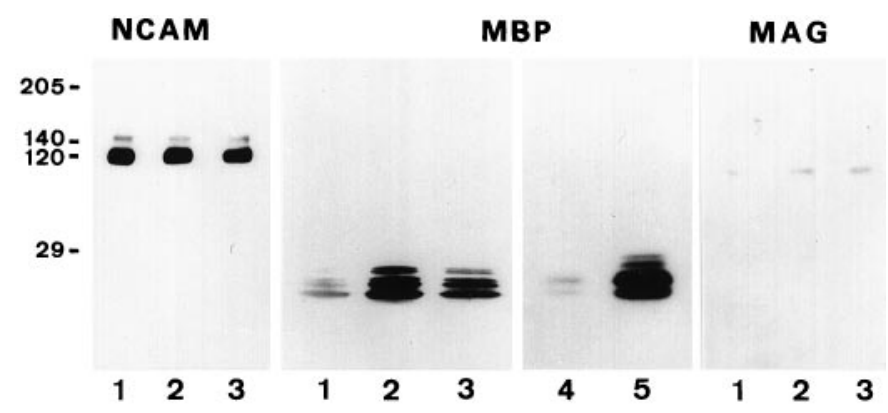

Figure 5. Western blot analysis of the expression of NCAM, MBP, and MAG by cultured OLs. OLs were maintained for $2 \mathrm{~d}$ in culture on PLL (lanes 1), PLL plus TN-R 160 (lanes 2, 4, 5), and PLL plus TN-R 180 (lanes 3 ), as described above. Lanes 4, 5, Fab' fragments of polyclonal antibodies to $\mathrm{TN}-\mathrm{R}(50 \mu \mathrm{g} / \mathrm{ml}$, lane 4$)$ or preimmune rabbit $\mathrm{IgG}(100 \mu \mathrm{g} / \mathrm{ml}$, lane 5$)$ were added to the cultures $2 \mathrm{hr}$ after plating. Protein extracts (from $1 \times$ $10^{6}$ cells/lane) were subjected to SDS-PAGE and Western blot analysis by using polyclonal antibodies to NCAM and MAG or monoclonal antibody to MBP. Antibody binding was visualized with HRP-conjugated secondary antibodies and the ECL method for detection (Amersham), according to the manufacturer's instructions. The apparent molecular weights (in $\mathrm{kDa}$ ) are shown at the left margin.

Approximately $10 \%$ of all cells were labeled by the antibody $\mathrm{A} 2 \mathrm{~B} 5$, thus defining these cells as $\mathrm{A} 2 \mathrm{~B}^{+}{ }^{+} 4^{+} \mathrm{O}-2 \mathrm{~A}$ progenitors. TN-R had a drastic effect on the differentiation of $\mathrm{O}^{+}$cells, because $>90 \%$ of the cells expressed GalC and, to a different extent, MBP and PLP in their cell bodies and processes. On PLL substrates $\sim 25 \%$ of the cells expressed low amounts of MBP and PLP, predominantly defined to the cytoplasm. The levels of expression of NCAM remained constant under all culture conditions (Table 1, Fig. 5).

To verify the upregulation of myelin protein expression by TN-R, we performed Western blot analyses of protein extracts prepared from OLs cultured for $2 \mathrm{~d}$ on PLL or PLL plus TN-R substrates (Fig. 5). The expression of NCAM, which in mature OLs is represented mainly by the $120 \mathrm{kDa}$ isoform and minor amounts of the $140 \mathrm{kDa}$ transmembrane isoform (Trotter et al., 1989), was not affected by TN-R. O4 ${ }^{+}$OLs maintained on TNR-containing substrates expressed high levels of MBP and MAG, whereas those on PLL contained hardly detectable amounts of these molecules. Cultured OLs expressed predominantly the low $M_{\mathrm{r}}$ isoforms of MBP characteristic for later developmental stages in vivo (Dubois-Dalcq et al., 1986; Monge et al., 1986; Campagnoni, 1988; Brophy et al., 1993). The upregulation of myelin protein expression by TN-R could be inhibited specifically by Fab' fragments of polyclonal antibodies to TN-R, but not by preimmune rabbit IgG (Fig. 5, for MBP).

\section{Autocrine regulation of tenascin-R expression by cultured $\mathrm{O4}^{+}$oligodendrocytes}

We further examined the effect of TN-R on the production of endogenous protein by cultured $\mathrm{O}^{+}$OLs (Figs. 6, 7). For the analysis of TN-R mRNA expression, we performed RT-PCR, using RNA from cells maintained on PLL or PLL plus TN-R 160 substrates. As control, the levels of mRNA expression of the housekeeping enzyme GAPDH in these cells were analyzed in parallel. In $\mathrm{O}^{+}$ OLs maintained on TN-R-containing substrates, a 2.5- to threefold increase in TN-R-specific mRNA expression was observed, while the levels of GAPDH mRNA remained constant (Figs. 6A, 7). The upregulation of TN-R mRNA expression was accompanied by an increased protein secretion (mainly TN-R 180), as demonstrated by Western blot analysis of medium conditioned by $\mathrm{O}^{+}$OLs maintained on PLL or PLL plus TN-R 160 (Fig. 6B). Under these conditions a two- to threefold increase in protein levels was detectable in the culture medium, as determined by sandwich ELISA of OL-conditioned media (Fig. 7).

\section{DISCUSSION}

Our findings demonstrate that two isoforms of an OL intrinsic molecule, TN-R 160 and TN-R 180, support the adhesion and process formation of OLs in vitro, a process mediated by the interaction with sulfated galactolipids, and results in a stimulation of OL maturation, i.e., upregulation of expression of myelin proteins (TN-R, MBP, MAG, and PLP) and GLs (GalC), suggesting an autocrine, TN-R-mediated mechanism of differentiation. Consistent with the regulatory role of $\mathrm{TN}-\mathrm{R}$ is the finding that TN-R mRNA and protein (Pesheva et al., 1989; Fuss et al., 1993 ) emerge in OLs before the expression of MAG, MBP, and PLP (Dubois-Dalcq et al., 1986; Monge et al., 1986; Ikenaka et al., 1991; Brophy et al., 1993). Beside Sulf and the structurally related seminolipids, $\mathrm{O} 4$ antibodies have been suggested to react with an as yet unknown molecule expressed by $\mathrm{O}^{+}$early progenitors, proligodendroblasts, in which Sulf synthesis was not detectable (Bansal et al., 1989, 1992), and we cannot rule out the possibility that at very early stages of OL development TN-R may interact also with this molecule. Later on, sulfated galactolipids represent the major TN-R receptor at the OL cell surface, because OLs of different postnatal age, i.e., differentiation state, continuously express Sulf in vivo and in vitro (Bansal and Pfeiffer, 1992). In addition, our findings on the (1) interaction of TN-R with galactose-containing GLs, i.e., GalC, galactosyl diglyceride, and psychosine, all of which are also recognized by the O1 antibody (Bansal et al., 1989), and (2) interference of the latter with OL-TN-R 180 interactions suggest that, with progressing maturation, TN-R may interact also with galactolipids at the OL cell surface. The effect of TN-R on OLs strikingly resembles the stimulation of OL differentiation in culture by $\mathrm{O} 4$ antibodies (Bansal et al., 1988). For the effect of O4 antibodies, it has been proposed that (1) cell aggregation could allow the concentration of an OL autocrine factor necessary for maturation, and (2) Sulf are involved functionally in the regulation of OL differentiation and myelination. Lipid and/or protein sulfation seems to be important for oligodendrocyte maturation (Bansal and Pfeiffer, 1994), and on the basis of our present finding that Sulf are cellular receptors for TN-R, we would like to postulate that TN-R stimulates the differentiation of OLs by a Sulf-mediated mechanism.

The signal transduction mechanism by which the interaction of 

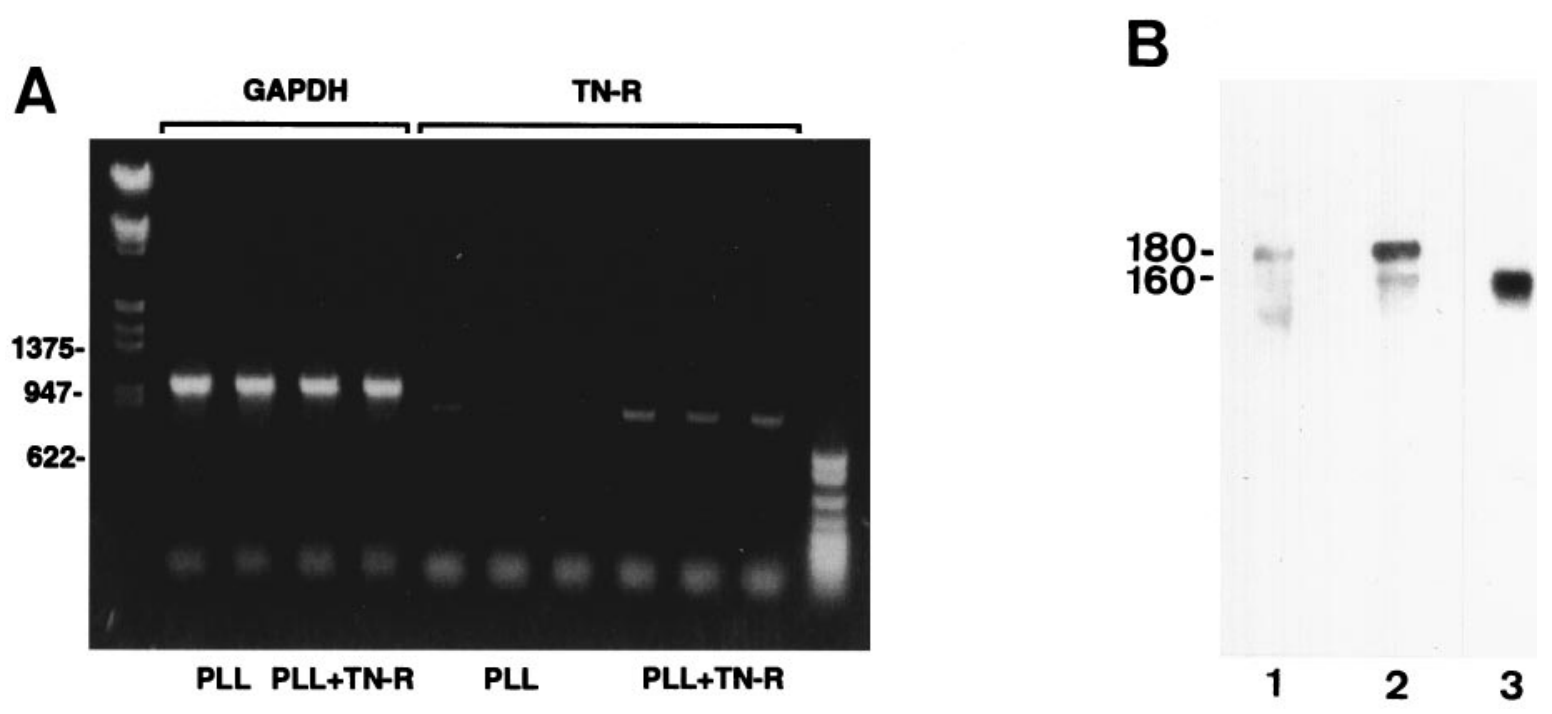

Figure 6. Effect of TN-R on TN-R mRNA and protein expression by cultured OLs, as determined by RT-PCR $(A)$ and Western blot analysis of OL-conditioned culture media $(B)$. OLs were maintained for $2 \mathrm{~d}$ in vitro on PLL or PLL plus TN-R 160 substrates, and poly $\left(\mathrm{A}^{+}\right) \mathrm{RNA}$ isolated from these cells was analyzed by RT-PCR. As control, GAPDH mRNA expression was analyzed in parallel. The apparent molecular weights of the DNA marker (in bp) are shown at the left margin in $A$. TN-R released into the culture medium from OLs maintained on PLL (B, lane 1) or PLL plus TN-R 160 (B, lane 2) was immunoprecipitated by using polyclonal antibodies to TN-R as a carrier. Immunoprecipitates and TN-R 160 used for the PLL plus TN-R 160 substrate $(B$, lane 3$)$ were subjected to SDS-PAGE and Western blot analysis by using monoclonal antibody 596 recognizing both TN-R isoforms. For ECL detection the Tropix Western-Light Plus kit was used according to the manufacturer's instructions. The apparent molecular weights of the two major TN-R isoforms (in $\mathrm{kDa}$ ) are shown at the left margin.

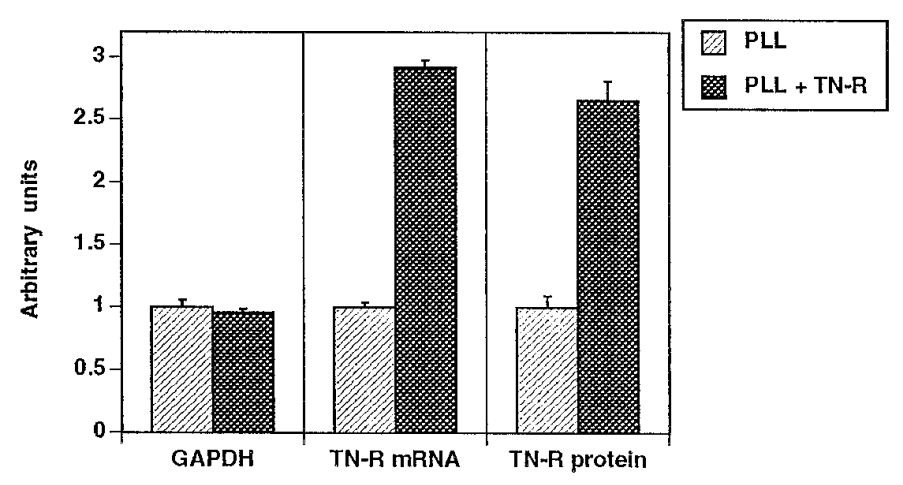

Figure 7. Quantitative data on the expression of TN-R mRNA and protein by cultured OLs, as shown in Figure 6. For the GAPDH- and TN-R-specific PCR products, band intensities (see Fig. $6 \mathrm{~A}$ ) were analyzed with National Institutes of Health Image software and are expressed as mean $\pm \mathrm{SD}$ of triplicate assays. For estimation of TN-R protein, OLconditioned SATO medium was analyzed by sandwich ELISA, using monoclonal antibodies to TN-R as a linker and polyclonal antibodies to $\mathrm{TN}-\mathrm{R}$ for detection. Values for the TN-R content under different culture conditions represent mean \pm SD performed in triplicate and plotted onto a standard curve prepared from purified TN-R (in the range from $5 \mu \mathrm{g} / \mathrm{ml}$ to $3 \mathrm{pg} / \mathrm{ml}$ ). In both experimental sets, values for GAPDH or TN-R from OLs maintained on PLL were set as 1.0.

membrane-associated sulfated and/or nonsulfated galactosphingolipids with TN-R regulates myelin gene expression is presently unknown. Agents raising the intracellular cAMP concentrations, in general, can induce myelin gene expression in both OLs and Schwann cells, suggesting the participation of this second messenger in the signaling cascade (Gandelman et al., 1989). Interaction with Sulf and GalC, in particular, induces calcium responses and rearrangement of the cytoskeleton in OLs (Dyer and Benjamins, 1990, 1991). These signals may be essential to OL maturation and subsequent myelination (Dyer, 1993) because anti-GalC antibodies inhibit myelination in vitro and in vivo (Fry et al., 1974; Ranscht et al., 1987; Bansal and Pfeiffer, 1989; Rosenbluth et al., 1994), and mice lacking the enzyme UDP-galactose/ceramide galactosyltransferase, which is required for the synthesis of GalC and Sulf, exhibit severe generalized tremoring and conduction deficits consistent with impaired function of the myelin sheath (Coetzee et al., 1996).

MBP, which comprises $\sim 30 \%$ of the myelin proteins in CNS myelin, first appears between the fifth and seventh day after birth when both mRNA and protein are detectable mostly in the cytoplasm (Campagnoni, 1988; Brophy et al., 1993). The migration of MBP mRNA and protein into the OL processes during development normally takes 6-12 d. On TN-R substrates this process is accomplished within 2-3 d in vitro when OLs heavily express the $14 \mathrm{kDa}$ protein isoform characteristic of mature myelin membranes in vivo. Additional studies have shown that this MBP isoform is sufficient for myelination in transgenic shiverer mice (Kimura et al., 1989).

Our present knowledge on the control of proliferation and differentiation of OL progenitors comes predominantly from studies on glial cell lineages in the rodent optic nerve and forebrain (Raff et al., 1983; Vaysse and Goldman, 1990; Noble, 1991; Barres and Raff, 1994). A simplified overview is shown in Figure 8 . In the presence of type- 1 astrocytes or astrocyteconditioned medium, the differentiation of $\mathrm{O}-2 \mathrm{~A}$ progenitors into OLs reproduces the in vivo development with a correct timing (Noble and Murray, 1984; Raff et al., 1985). One of the factors responsible for the effects of type-1 astrocytes was found to be platelet-derived growth factor (PDGF) (Noble et al., 1988; Raff et al., 1988; Richardson et al., 1988). The molecular mechanism by which the O-2A cells stop to proliferate and differentiate terminally remained, however, obscure because OLs continue to express functional PDGF receptors (Hart et al., 1989a,b). We have shown that one of the effects of $\mathrm{PDGF}$ on $\mathrm{O}-2 \mathrm{~A}$ progenitors is the upregulation of TN-R expression (Jung et al., 1993). Because TN-R stimulates OL maturation in the absence of PDGF, the timed differentiation 


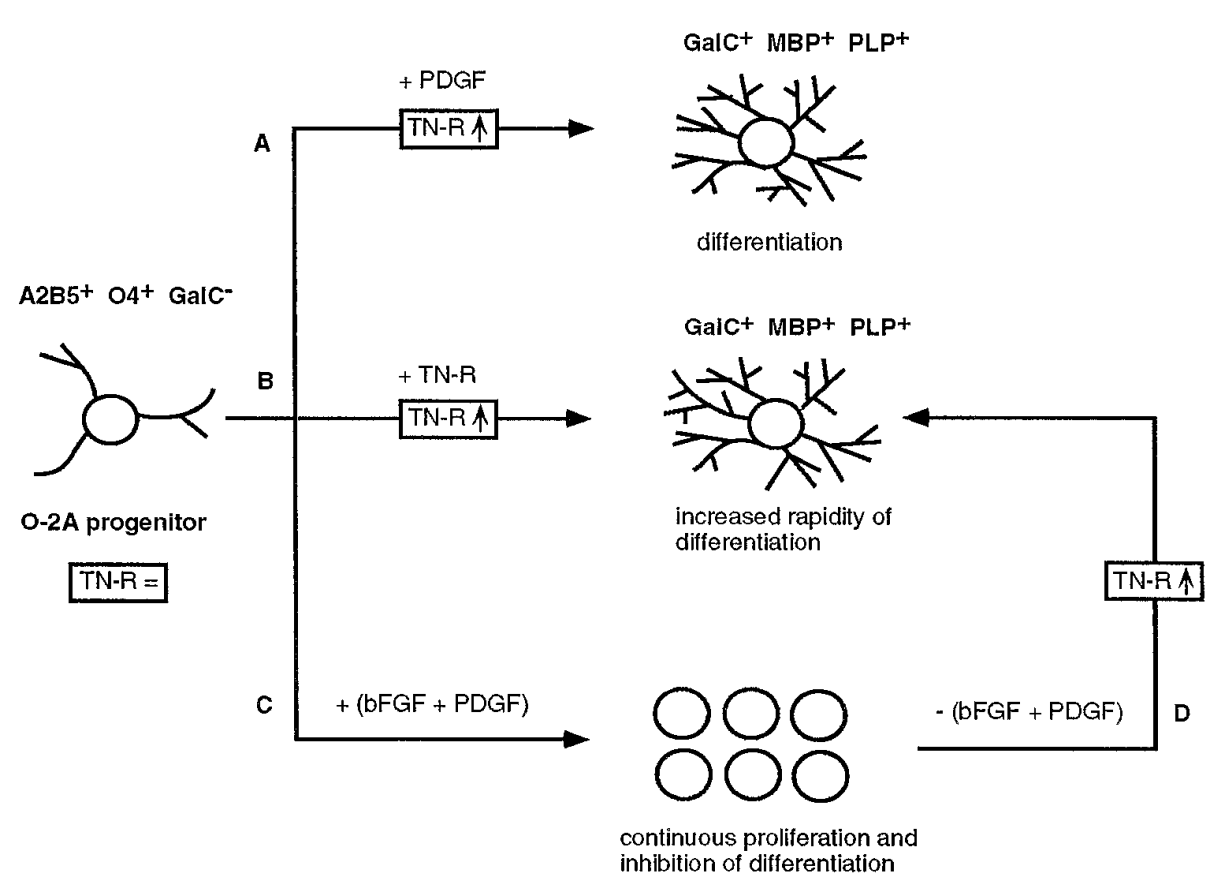

Figure 8. Hypothetical model on the molecular control of $\mathrm{O}-2 \mathrm{~A}$ progenitor cell $\left(\mathrm{A} 2 \mathrm{~B} 5^{+} \mathrm{O}^{+} \mathrm{GalC}^{-}\right.$) differentiation into mature OLs-a recapitulation of the data in the literature from the viewpoint of TN-R. O-2A progenitors express relatively low amounts of TN-R $(T N-R=)$. PDGF drives the clock that times $\mathrm{O}-2 \mathrm{~A}$ cell differentiation into $\mathrm{GalC}^{+}$ OLs $(A)$. The effect of PDGF likely is attributable to the upregulation of TN-R expression by $\mathrm{O}-2 \mathrm{~A}$ cells $(T N-R \uparrow)$, which, in turn, stimulates their terminal differentiation into myelin-forming cells $\left(\mathrm{GalC}^{+} \mathrm{MBP}^{+} \mathrm{PLP}^{+}\right)$, because TN-R alone upregulates its own expression and induces the terminal differentiation of O-2A progenitors in the absence of $\operatorname{PDGF}(B)$. The simultaneous action of bFGF and PDGF leads to continuous cell proliferation and inhibition of differentiation by a mechanism that interferes with the differentiation-inducing activity of PDGF $(C)$. On removal of the two growth factors $(D)$, a critical threshold of intrinsic TN-R expression ( $T N-R \uparrow)$ then would be a prerequisite for the ensuing rapid differentiation of $\mathrm{O}-2 \mathrm{~A}$ cells, similar to $B$. This model does not discriminate whether the upregulation of TN-R expression occurs in the presence and/or after the removal of the mitogens. TN-R thus may represent an intrinsic differentiation factor, the expression of which is subject to regulation by growth factors. of OLs in the presence of PDGF probably is attributable to the accumulation of TN-R in these cultures to a critical threshold, triggering the differentiation program. Neurons could be important in the regulation of progenitor cell proliferation in vivo because they are one of the sources for mitogens, such as basic fibroblast growth factor (bFGF) and PDGF (Gard and Pfeiffer, 1990; Yeh et al., 1991; Araujo and Cotman, 1992). O-2A cells proliferate in response to bFGF (McKinnon et al., 1990), and exposure to both bFGF and PDGF promotes the continuous proliferation of progenitor cells (Bögler et al., 1990). On removal of PDGF and bFGF from these cultures, O-2A progenitors stop dividing and differentiate very rapidly. Because bFGF (Jung et al., 1993) and exposure to both bFGF and PDGF (P. Pesheva and R. Probstmeier, unpublished observations) have no effect on the expression of TN-R by cultured OLs, the increased rapidity of OL differentiation could be attributable to the differentiation-inducing effect of TN-R in the absence of the mitogens. Precursor cell proliferation depends, however, on multiple signals from other cell types: ciliary neurotrophic factor (CNTF) enhances the rate of OL generation (Mayer et al., 1994; Barres et al., 1996), whereas PDGF, neurotrophin-3 (NT-3), and insulin-like growth factor (IGF-1) induce the proliferation and differentiation of OL precursors; the three growth factors also promote the survival of these cells in culture (Barres et al., 1992, 1993, 1994b). Whereas proliferation is driven by these growth factors, all of which bind to receptor tyrosine kinases, the effector mechanism inducing differentiation seems to depend on (1) thyroid hormones, glucocorticoids, and retinoic acid that activate intracellular receptors (Barres et al., 1994a; Barres and Raff, 1994) and/or (2) the accumulation of intrinsic molecules such as TN-R that trigger extracellular receptors (this study). The control of timed generation of OLs seems, however, to be more complex than previously suggested. A recent study providing a careful analysis of such timing mechanisms in vitro gives evidence, in fact, that thyroid hormone modulates the extent of OL generation within O-2A progenitor cell clones, but it does not alter the probability of individual clones to generate at least one OL, i.e., the mechanism inducing the initial generation of OLs seems to be cell-intrinsic, thyroid hormone-independent, whereas the regulation of progenitor self-renewal is cellextrinsic because it can be modulated by a variety of signaling molecules such as thyroid hormone (Ibarrola et al., 1996).

After trauma or in demyelinating diseases, the generation of new OLs with potential for myelination is likely to occur by the proliferation of O-2A $\mathrm{A}^{\text {adult }}$ progenitors or mature OLs (Ludwin, 1984; Raine et al., 1988; Wood and Bunge, 1991). In the spinal cord of adult mice, demyelinating lesions lead to the induction of FGF expression (Tourbah et al., 1992) and the proliferation of $\mathrm{O}^{+}{ }^{+}$and $\mathrm{O}^{+}{ }^{+} \mathrm{GFAP}^{+}$cells (Godfraind et al., 1989), suggesting that an FGF-induced proliferation of $\mathrm{O}-2 \mathrm{~A}$ progenitors in this part of the CNS may give rise to new OLs $\left(\mathrm{O}^{+}\right)$with remyelination capacity and type- 2 astrocytes $\left(\mathrm{O}^{+} \mathrm{GFAP}^{+}\right)$. The generation of these two glial cell types is very similar to the O-2A cell lineage in the optic nerve, where both OLs and type- 2 astrocytes express TN-R (Bartsch et al., 1993). Transplanted type-1 astrocytes support remyelination by host OLs in vivo (Franklin et al., 1991) and are probably the main source for oligodendrotrophic factors or factors that protect OLs against tumor necrosis factor (TNF)-induced and natural death, such as FGF, PDGF, NT-3, IGF-1, CNTF, leukemia inhibitory factor (LIF), interleukin-2 (IL-2), and IL-6 (Araujo and Cotman, 1992; Eddleston and Mucke, 1993; Louis et al., 1993; Mayer et al., 1994; Hopkins and Rothwell, 1995; Sawada et al., 1995). In the context of our present findings, current studies of ours demonstrate that growth factors and cytokines found to be produced by reactive astrocytes and activated microglia in association with different CNS pathologies (Scolding et al., 1994; Rothwell and Hopkins, 1995; Kreutzberg, 1996) can influence the expression of TN-R by OLs and thus affect the remyelinating capacity of these cells during demyelinating 
diseases such as multiple sclerosis or other neurodegenerative processes in the human CNS.

\section{REFERENCES}

Araujo DM, Cotman CW (1992) Basic FGF in astroglial, microglial, and neuronal cultures: characterization of binding sites and modulation of release by lymphokines and trophic factors. J Neurosci 12:1668-1678.

Bansal R, Pfeiffer SE (1989) Reversible inhibition of oligodendrocyte progenitor differentiation by a monoclonal antibody against surface galactolipids. Proc Natl Acad Sci USA 86:6181-6185.

Bansal R, Pfeiffer SE (1992) A novel stage in the oligodendrocyte lineage defined by the reactivity of progenitors with $\mathrm{R}-\mathrm{mAb}$ prior to $\mathrm{O} 1$ antigalactocerebroside. J Neurosci Res 32:309-316.

Bansal R, Pfeiffer SE (1994) Inhibition of protein and lipid sulfation in oligodendrocytes blocks biological responses to FGF-2 and retards cytoarchitectural maturation, but not developmental lineage progression. Dev Biol 162:511-524.

Bansal R, Gard AL, Pfeiffer SE (1988) Stimulation of oligodendrocyte differentiation in culture by growth in the presence of a monoclonal antibody to sulfated glycolipid. J Neurosci Res 21:260-267.

Bansal R, Warrington AE, Gard AL, Ranscht B, Pfeiffer SE (1989) Multiple and novel specificities of monoclonal antibodies O1, O4, $\mathrm{R}-\mathrm{mAb}$ used in the analysis of oligodendrocyte development. J Neurosci Res 24:548-557.

Bansal R, Stefansson K, Pfeiffer SE (1992) Proligodendroblast antigen (POA), a developmental antigen expressed by A007/O4-positive oligodendrocyte progenitors prior to the appearance of sulfatide and galactocerebroside. J Neurochem 58:2221-2229.

Barres BA, Raff MC (1994) Control of oligodendrocyte number in the developing rat optic nerve. Neuron 12:935-942.

Barres BA, Hart IK, Coles HSR, Burne JE, Voyvodic JT, Richardson WD, Raff MC (1992) Cell death and control of cell survival in the oligodendrocyte lineage. Cell 70:31-46.

Barres BA, Schmid R, Sendtner M, Raff MC (1993) Multiple extracellular signals are required for long-term oligodendrocyte survival. Development (Camb) 118:283-295.

Barres BA, Lazar M, Raff MC (1994a) A novel role for thyroid hormone, glucocorticoids, and retinoic acid in timing oligodendrocyte differentiation. Development (Camb) 120:1097-1108.

Barres BA, Raff MC, Gaese F, Bartke I, Dechant G, Barde YA (1994b) A crucial role for neurotrophin-3 in oligodendrocyte development. Nature 367:371-375.

Barres BA, Burne JF, Holtmann B, Thoenen H, Sendtner M, Raff MC (1996) Ciliary neurotrophic factor enhances the rate of oligodendrocyte generation. Mol Cell Neurosci 8:146-156.

Bartsch U, Pesheva P, Raff M, Schachner M (1993) Expression of janusin (J1-160/180) in the retina and optic nerve of the developing and adult mouse. Glia 9:57-69.

Bögler O, Wren D, Barnett SC, Land H, Noble M (1990) Cooperation between two growth factors promotes extended self-renewal and inhibits differentiation of O-2A progenitor cells. Proc Natl Acad Sci USA 87:6368-6372.

Brophy PJ, Boccaccio GL, Colman DR (1993) The distribution of myelin basic protein mRNAs within myelinating oligodendrocytes. Trends Neurosci 16:515-521.

Brunner C, Lassmann H, Waehneldt TV, Matthieu J-M, Linington C (1989) Differential ultrastructural localization of myelin basic protein, myelin/oligodendroglial glycoprotein, and 2',3'-cyclic nucleotide $3^{\prime}$ phosphodiesterase in the CNS of adult rats. J Neurochem 52:296-304.

Campagnoni AT (1988) Molecular biology of myelin proteins from the central nervous system. J Neurochem 51:1-14.

Cardwell MC, Rome LH (1988a) Evidence that an RGD-dependent receptor mediates the binding of oligodendrocytes to a novel ligand in a glial-derived matrix. J Cell Biol 107:1541-1549.

Cardwell MC, Rome LH (1988b) RGD-containing peptides inhibit the synthesis of myelin-like membrane by cultured oligodendrocytes. J Cell Biol 107:1551-1559.

Carnemolla B, Leprini A, Borsi L, Querzé G, Urbini S, Zardi L (1996) Human tenascin-R. Complete primary structure, pre-mRNA alternative splicing, and gene localization on chromosome 1q23-q24. J Biol Chem 14:8157-8160.

Coetzee T, Fujita N, Dupree J, Shi R, Blight A, Suzuki K, Suzuki K, Popko $\mathrm{B}$ (1996) Myelination in the absence of galactocerebroside and sulfatide: normal structure with abnormal function and regional instability. Cell 86:209-219.
Dubois-Dalcq M, Behar T, Hudson L, Lazzarini RA (1986) Emergence of three myelin proteins in oligodendrocytes cultured without neurons. J Cell Biol 102:384-392.

Dyer CA (1993) Novel oligodendrocyte transmembrane signaling systems. Mol Neurobiol 7:1-22.

Dyer CA, Benjamins JA (1990) Glycolipids and transmembrane signaling: antibodies to galactocerebroside cause a calcium influx in oligodendrocytes. J Cell Biol 111:625-633.

Dyer CA, Benjamins JA (1991) Galactocerebroside and sulfatide independently mediate $\mathrm{Ca}^{2+}$ responses in oligodendrocytes. J Neurosci Res 30:699-711.

Eddleston M, Mucke L (1993) Molecular profile of reactive astrocytesimplications for their role in neurologic disease. Neuroscience 54:15-36.

Erickson HP (1993) Tenascin-C, tenascin-R, and tenascin-X: a family of talented proteins in search of functions. Curr Opin Cell Biol 5:869-876.

Franklin RJ, Crang AJ, Blakemore WF (1991) Transplanted type-1 astrocytes facilitate repair of demyelinating lesions by host oligodendrocytes in adult rat spinal cord. J Neurocytol 20:420-430.

Fredman P, Magnani JL, Nirenberg M, Ginsburg V (1984) Monoclonal antibody A2B5 reacts with many gangliosides in neuronal tissue. Arch Biochem Biophys 233:661-666.

Fry JM, Weissbarth S, Lehrer GM (1974) Cerebroside antibody inhibits sulfatide synthesis and myelination and demyelinates in cord tissue cultures. Science 183:540-542.

Fuss B, Wintergerst ES, Bartsch U, Schachner M (1993) Molecular characterization and in situ messenger RNA localization of the neural recognition molecule $\mathrm{J} 1-160 / 180$ - a modular structure similar to tenascin. J Cell Biol 120:1237-1249.

Gandelman K-Y, Pfeiffer SE, Carson JH (1989) Cyclic AMP regulation of $\mathrm{P} 0$ glycoprotein and myelin basic protein gene expression in semidifferentiated peripheral neurinoma cell line D6P2T. Development (Camb) 106:389-398.

Gard AL, Pfeiffer SE (1989) Oligodendrocyte progenitors isolated directly from developing telencephalon at a specific phenotypic stage: myelinogenic potential in a defined environment. Development (Camb) 106:119-132.

Gard AL, Pfeiffer SE (1990) Two proliferative stages of the oligodendrocyte lineage (A2B5 ${ }^{+} \mathrm{O}^{-}$and $\mathrm{O}^{+}{ }^{+} \mathrm{GalC}^{-}$) under different mitogenic control. Neuron 5:615-625.

Godfraind C, Friedrich VL, Holmes KV, Dubois-Dalcq M (1989) In vivo analysis of glial cell phenotypes during a viral demyelinating disease in mice. J Cell Biol 109:2405-2416.

Goldman JE, Vaysse PJ (1991) Tracing glial cell lineages in the mammalian forebrain. Glia 4:149-156.

Hakomori S-H, Siddiqui B (1974) Isolation and characterization of glycosphingolipids from animal cells and their membranes. Methods Enzymol 32:345-367.

Hansson CG, Karlsson K, Samuelsson BE (1978) The identification of sulphatides in human erythrocyte membrane and their relation to sodium-potassium-dependent adenosine triphosphate. J Biochem 83:813-819.

Hart IK, Richardson WD, Bolsover SR, Raff MC (1989a) PDGF and intracellular signaling in the timing of oligodendrocyte differentiation. J Cell Biol 109:3411-3417.

Hart IK, Richardson WD, Heldin CH, Westermark B, Raff MC (1989b) PDGF receptors on cells of the oligodendrocyte-type-2 astrocyte (O2A) cell lineage. Development (Camb) 105:596-604.

Hopkins SJ, Rothwell NJ (1995) Cytokines and the nervous system I: expression and recognition. Trends Neurosci 18:83-88.

Ibarrola N, Mayer-Pröschel M, Rodriguez-Pena A, Noble M (1996) Evidence for the existence of at least two timing mechanisms that contribute to oligodendrocyte generation in vitro. Dev Biol 180:1-21.

Ikenaka K, Okano H, Tamura T, Mikoshiba K (1991) Recent advances in studies on genes for myelin proteins. Dev Growth Differ 33:181-192.

Jessen KR, Mirsky R (1991) Schwann cell precursors and their development. Glia 4:185-194.

Jung M, Pesheva P, Schachner M, Trotter J (1993) Astrocytes and neurons regulate the expression of the neural recognition molecule janusin by cultured oligodendrocytes. Glia 9:163-175.

Kimura M, Sato M, Akatsuka A, Nozawa-Kimura S, Takahashi R, Yokoyama M, Nomura T, Katsuki M (1989) Restoration of myelin formation by a single type of myelin basic protein in transgenic shiverer mice. Proc Natl Acad Sci USA 86:5661-5665.

Kreutzberg GW (1996) Microglia: a sensor for pathological events in the CNS. Trends Neurosci 19:312-318. 
Künemund V, Jungalwala FB, Fischer G, Chou DKH, Keilhauer G, Schachner M (1988) The L2/HNK-1 carbohydrate of neural cell adhesion molecules is involved in cell interactions. J Cell Biol 106:213-223.

Louis J-C, Magal E, Takayama S, Varon S (1993) CNTF protection of oligodendrocytes against natural and tumor necrosis factor-induced death. Science 259:689-692.

Ludwin SK (1984) Proliferation of mature oligodendrocytes after trauma to the central nervous system. Nature 308:274-275.

Mayer M, Bhakoo K, Noble M (1994) CNTF and LIF promote the generation, maturation, and survival of oligodendrocytes in vitro. Development (Camb) 120:143-153.

McKinnon RD, Matsui T, Dubois-Dalcq M, Aaronson SA (1990) FGF modulates the PDGF-driven pathway of oligodendrocyte development. Neuron 5:603-614.

Miller RH (1996) Oligodendrocyte origins. Trends Neurosci 19:92-96.

Monge M, Kadiiski D, Jacque CM, Zalc B (1986) Oligodendroglial expression and deposition of four myelin constituents in the myelin sheath during development: an in vivo study. Dev Neurosci 8:222-235.

Morganti MC, Taylor J, Pesheva P, Schachner M (1990) Oligodendrocyte-derived J1-160/180 extracellular matrix glycoproteins are adhesive or repulsive, depending on the partner cell type and time of interaction. Exp Neurol 109:98-110.

Noble M (1991) Points of controversy in the O-2A lineage: clocks and type-2 astrocytes. Glia 4:157-164.

Noble M, Murray K (1984) Purified astrocytes promote the in vitro division of a bipotential glial progenitor cell. EMBO J 3:2243-2247.

Noble M, Murray K, Stroobant P, Waterfield M, Riddle P (1988) Platelet-derived growth factor promotes division and motility and inhibits premature differentiation of the oligodendrocyte-type-2 astrocyte progenitor cell. Nature 333:560-562.

Nowak TP, Haywood PL, Barondes SH (1976) Developmentally regulated lectin in embryonic chick pectoral muscle and a myogenic cell line. Biochem Biophys Res Commun 68:650-657.

Pesheva P, Spiess E, Schachner M (1989) J1-160 and J1-180 are oligodendrocyte-secreted nonpermissive substrates for cell adhesion. J Cell Biol 109:1765-1778.

Pesheva P, Probstmeier R, Spiess E, Schachner M (1991) Divalent cations modulate the inhibitory substrate properties of murine glialderived J1-160 and J1-180 extracellular matrix glycoproteins for neuronal adhesion. Eur J Neurosci 3:356-365.

Pesheva P, Gennarini G, Goridis C, Schachner M (1993) The F3/11 cell adhesion molecule mediates the repulsion of neurons by the extracellular matrix glycoprotein J1-160/180. Neuron 10:69-82.

Probstmeier R, Martini R, Tacke R, Schachner M (1990) Expression of the adhesion molecules L1, N-CAM, and J1/tenascin during development of the murine small intestine. Differentiation 44:42-55.

Raff MC, Miller RH, Noble M (1983) A glial progenitor cell that develops into an astrocyte or an oligodendrocyte, depending on the culture medium. Nature 303:390-396.

Raff MC, Abney ER, Fok-Seang J (1985) Reconstitution of a developmental clock in vitro: a critical role for astrocytes in the timing of oligodendrocyte differentiation. Cell 42:61-69.

Raff MC, Lillien LE, Richardson WD, Burne JF, Noble M (1988)
Platelet-derived growth factor from astrocytes drives the clock that times oligodendrocyte development in culture. Nature 333:562-565.

Raine CS, Moore GR, Hintzen R, Traugott N (1988) Induction of oligodendrocyte proliferation and remyelination after chronic demyelination. Relevance to multiple sclerosis. Lab Invest 59:467-476.

Ranscht B, Wood PA, Bunge RP (1987) Inhibition of in vitro peripheral myelin formation by monoclonal anti-galactocerebroside. J Neurosci 7:2936-2947.

Richardson WD, Pringle N, Mosley M, Westermark B, Dubois-Dalcq M (1988) A role for the platelet-derived growth factor in normal gliogenesis in the central nervous system. Cell 53:309-319.

Rosenbluth J, Liu Z, Guo D, Schiff R (1994) Inhibition of CNS myelin development in vivo by implantation of anti-GalC hybridoma cells. J Neurocytol 23:699-707.

Rothwell NJ, Hopkins SJ (1995) Cytokines and the nervous system. II. Actions and mechanisms of action. Trends Neurosci 18:130-136.

Rozeik C, Von Keyserlingk D (1987) The sequence of myelination in the brainstem of the rat monitored by myelin basic protein immunohistochemistry. Dev Brain Res 35:183-190.

Sawada M, Suzumura A, Marunouchi T (1995) Cytokine network in the central nervous system and its roles in growth and differentiation of glial and neuronal cells. Int J Dev Neurosci 13:253-264.

Schwab ME, Schnell L (1989) Region-specific appearance of myelin constituents in the developing rat spinal cord. J Neurocytol 18:161-169.

Scolding NJ, Zajicek JP, Wood N, Compston DAS (1994) The pathogenesis of demyelinating disease. Prog Neurobiol 43:143-173.

Skoff RP, Knapp PE (1991) Division of astroblasts and oligodendroblasts in postnatal rodent brain: evidence for separate astrocyte and oligodendrocyte lineages. Glia 4:165-174.

Taylor J, Pesheva P, Schachner M (1993) Influence of janusin and tenascin on growth cone behavior in vitro. J Neurosci Res 35:347-362.

Tourbah A, Baron-Van Evercooren A, Oliver L, Raulais D, Jeanny JC, Gumpel M (1992) Endogenous aFGF expression and cellular changes after a demyelinating lesion in the spinal cord of adult normal mice: immunohistochemical study. J Neurosci Res 33:47-59.

Trotter J, Bitter-Suermann D, Schachner M (1989) Differentiationregulated loss of the polysialylated embryonic form and expression of the different polypeptides of the neural cell adhesion molecule by oligodendrocytes and myelin. J Neurosci Res 22:369-383.

Vaysse PJ-J, Goldman JE (1990) A clonal analysis of glial lineages in neonatal forebrain development in vitro. Neuron 5:227-235.

Warrington AE, Pfeiffer SE (1992) Proliferation and differentiation of $\mathrm{O}^{+}{ }^{+}$oligodendrocytes in postnatal rat cerebellum: analysis in unfixed tissue slices using anti-glycolipid antibodies. J Neurosci Res 33:338-353.

Wintergerst ES, Fuss B, Bartsch U (1993) Localization of janusin mRNA in the central nervous system of the developing and adult mouse. Eur J Neurosci 5:299-309.

Wood PM, Bunge RP (1991) The origin of remyelinating cells in the adult central nervous system: the role of the mature oligodendrocyte. Glia 4:225-232.

Yeh H-J, Riut KG, Wang Y-X, Parks WC, Snider WD, Deuel TF (1991) PDGF A-chain gene is expressed by mammalian neurons during development and in maturity. Cell 64:209-216. 